International Journal of Business Management and Economic Review

Vol. 4, No. $03 ; 2021$

ISSN: 2581-4664

\title{
THE EFFECT OF MECHANICAL WORKER COMPETENCY STANDARDIZATION ON ITS OPERATIONAL ADVANTAGE THROUGH WORKER PRODUCTIVITY AND PRODUCTION UNIT PRODUCTIVITY OFPT CIPTA KRIDATAMA SITE MIFA
}

\author{
Badruzzaman Timora, Hafasnuddin and Sofyan \\ Management Department, UniversitasSyiah Kuala, Indonesia \\ http://doi.org/10.35409/IJBMER.2021.3261
}

\begin{abstract}
This study intends to examine the effect of standardization of mechanical worker competence on company operational excellence through worker productivity and production unit productivity at PT CiptaKridatama Site Mifa (PT. Mifa) located in Meulaboh City, Aceh Barat, Indonesia. The population of this research was all employees of PT. Mifa, amounting to 802 people. The number of sample in this research was 267 people who were determined using the Slovin formula which was taken based on the work unit. Data were analyzed using Structural Equation Modeling (SEM) with the help of the Amos application. Research results prove that that in PT. Mifa, competency standardization of mechanical workers, company operational excellence, worker productivity and production unit productivity are good; there is an effect of competency standardization of mechanical workers on worker productivity; there is an effect of competency standardization of mechanical workers on the production unit productivity; there is an effect of worker productivity on operational excellence; there is an effect of the production unit productivity on operational excellence; there is an effect of competency standardization of mechanical workers on operational excellence; there is an effect of competency standardization of mechanical workers on operational excellence through worker productivity, and ; there is an effect of competency standardization of mechanical workers on operational excellence through production unit productivity. This research model also reveals that worker productivity and production unit productivity can be as a partial mediation so that PT. Mifa achieves operational excellence. It can be said that by increasing competency standards, it will have an impact on the achievement of operational excellence either directly or through the mediation of worker productivity and productivity of production units. All these findings reveal that this research model can be implemented in the research object, namely PT. Mifa to achieve its operational excellence. For future research, researchers are currently encouraging that this tested model can be further developed by adding other variables such as workload and work stress which are closely related to the achievement of company operational excellence
\end{abstract}

Keyword: Competency Standardization, Operational Excellence, Worker Productivity, Productivity of Production Units.

\section{INTRODUCTION}

PT CiptaKridatama Site Mifa (PT. Mifa), located in Meulaboh City, Indonesia, is a company in 


\section{International Journal of Business Management and Economic Review}

Vol. 4, No. 03; 2021

ISSN: 2581-4664

the field of mining service providers, which is a subsidiary of PT. Adi BaniratnaMakmur Investama or often called PT. ABM Investama which joins the large Tiara MargaTrakindo group. The fierce competition in the industrial world causes every company to always be able to increase its operational excellence. Operational excellence manifests itself through integrated performance across revenues, costs and risks. It focuses on meeting customer expectations through continuous improvement of operational processes and organizational culture.

To increase the company's operational excellence, it requires competency standards for each workforce, so that with this competency, a company is able to compete and increase the productivity of each existing workforce. Competency standards for each workforce of course vary according to the needs of the company and the functions of each workforce. To be able to achieve the goals of the company, the management of the company must continue to strive so that members or workers involved in organizational activities can show their achievements in the form of work productivity to realize the goals that have been planned.

Based on the current phenomenon, it shows that there has been a decrease in work productivity and productivity of the production units at PT. Mifa, where this decline is caused by the presence of worker competency standards, especially in the mechanical field that is not in accordance with the needs of the company, it can be seen that most of the mechanical labor used in the production process is local workers who do not have competence and experience in the field of coal production. The use of local labor is caused by demands from the local government that the company must accommodate local workers to be employed in several production units. The demand from the local government has an indirect impact on the low productivity of the workforce which results in the low operational excellence of the company. To prevent the continued decline in productivity, the leaders and management of PT CiptaKridatama Site MifaMeulaboh must further improve the mechanical competency standards that are owned in the company.

\section{STUDY OF LITERATURE}

\section{Company Operational Excellence}

(Nyiramahoro \& Shooshina, 2001)revealed that operational excellence means the company's ability to run an existing business to generate sustainable profits using existing assets. The concept of excellence in general has been developed and used to describe a system that significantly improves performance, including in the field of operations(Edgeman \& Eskildsen, 2014)

Operational excellence will be closely related to profitability which can be maximized by increasing the production area and geographic market(Nyiramahoro \& Shooshina, 2001). In this research, operational excellence is measured using indicators as disclosed by(Nyiramahoro \& Shooshina, 2001)namely increased production, increased sales volume, increased value-added products, increased costs and high market demand.

\section{Work productivity}

According to(Margiati, 2010)worker productivity is the output produced by functions or individuals in a particular job or profession.(Engko, 2008)defined worker productivity as individual work performance which is regulated based on the standards or criteria established by an organization. (Rahmah, 2019)explained that labor productivity is the level of labor ability to 


\section{International Journal of Business Management and Economic Review}

Vol. 4, No. 03; 2021

ISSN: 2581-4664

produce a product or complete a certain volume of work within a certain time limit under standard conditions and is measured in volume units / person-day. In this research, worker productivity is measured using indicators as disclosed by(Ratminto \& Winarsih, 2008)namely quality of work, the quantity of work, timeliness, effectiveness, independence, and work commitment.

\section{Productivity of the Production Unit}

The production unit is part of an organization that has an important and vital role in maintaining the sustainability of an organization.(Surjadi, 2009)defined the productivity of the production unit as the totality of the work achieved by an organization, the achievement of organizational goals means that, the performance of an organization can be seen from the extent to which the organization can achieve goals based on predetermined goals. Meanwhile(Sobandi et al., 2006)defined the productivity of the production unit as something that has been achieved by the organization within a certain period, whether related to input, output, outcome, benefit, or impact.

Meanwhile, in Menpan Decree No. 63 / KEP / M.PAN / 7/2003 stated the productivity of the production unit is the extent to which the organization can achieve goals based on previously set goals. Measurement of the productivity of the production unit can be measured using the indicators stipulated in the Minister of Agriculture Decree Number 63 / KEP / M.PAN / 7/2003, namely service procedures, service requirements, employee discipline, employee responsibility, speed of service, politeness and friendliness, the certainty of service costs, the certainty of service schedules, environmental security, and service security.

\section{Competency standards}

According to(Yasir \& Majid, 2017)competency standardizationis a framework that explains the basis for developing a structured learning program.(Wibowo, 2016)explained that every organization is formed to achieve certain goals and if it is achieved then it can be called a success. (Hartati, 2005)revealed that competence is the ability to carry out tasks in accordance with the knowledge and skills as well as technology and experience relevant to the task field so that it can develop the work motivation concerned and increase its performance.

Improvement of human resources at PT. Mifa continues to be carried out through programs such as employee training and development. The measurement of competency standards in this research is specifically for mechanics at PT. Mifa, using indicators as disclosed by(Wibowo, 2016)namely operational skills, broad insight, mastering learning media, mastery of technology, good personality and being a good role model.

\section{Conceptual Framework and Research Hypotheses}

This research conceptual framework can be described as follows: 


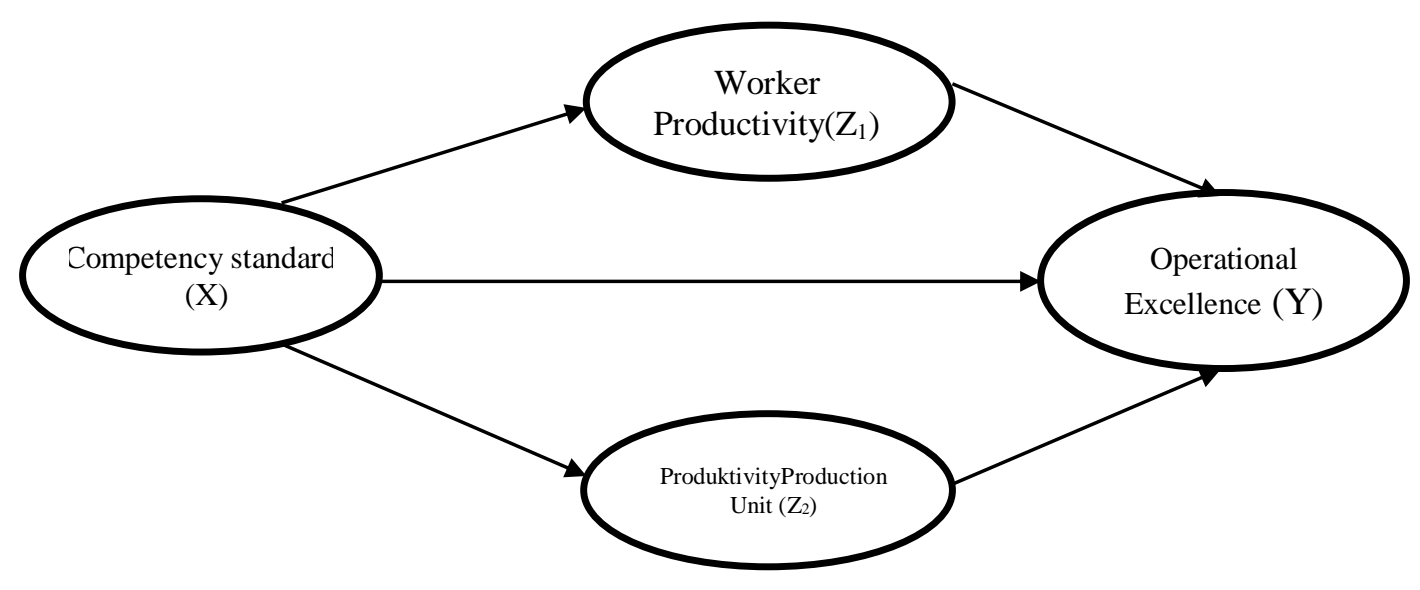

Figure 1. Conceptual Framework

Ha1: competencystandardization of mechanical workers, company operational excellence, worker productivity and production unitproductivity at PT. Mifaaregood.

$\mathrm{Ha} 2$ : There is an effect of competencystandardization of mechanical workers on worker productivity at PT. Mifa.

Ha3: There is an effect of competencystandardization of mechanical workers on the production unit productivity at PT. Mifa.

Ha4: There is an effect of worker productivity on operational excellence at PT. Mifa.

Ha5: There is an effect of the production unit productivity on operational excellence at PT. Mifa

Ha6: There is an effect of competencystandardization of mechanical workers on operational excellence at PT. Mifa.

Ha7: There is an effect of competencystandardization of mechanical workers on operational excellence through Worker Productivity at PT. Mifa.

Ha8: There is an effect of competencystandardization of mechanical workers on operational excellence through production unit productivity at PT. Mifa.

\section{RESEARCH METHOD}

This research was conducted at PT. Mifa. The research variables are competency standards, company operational excellence, worker productivity, and production unit productivity. The population of this research was all employees of PT. Mifa, amounting to 802 people. The number of sample in this research was 267 people who were determined using the Slovin formula which was taken based on the work unit as follows. 
International Journal of Business Management and Economic Review

Vol. 4, No. 03; 2021

ISSN: 2581-4664

Table 1 Sample Proportion Based on Work Units

\begin{tabular}{|c|c|c|c|}
\hline No. & Work Unit & $\begin{array}{r}\mathrm{P} \\
\text { opulation }\end{array}$ & $\begin{array}{l}\quad \text { Sample } \\
\text { Proportion } \\
\text { (People) }\end{array}$ \\
\hline & Warehouse \& Inventory Control & 45 & $=15^{\frac{45}{802} \times 267}$ \\
\hline & HR \& GA Superintendent & 185 & $=62^{\frac{185}{802} \times 267}$ \\
\hline & Foreman's safety & 132 & $=44^{\frac{132}{802} \times 267}$ \\
\hline & Port Infrastructure \& Services & 134 & $\frac{134}{802} \times 267$ \\
\hline & Civil \& Road Maintenance & 141 & $=47^{\frac{141}{802} \times 267}$ \\
\hline & Procurement Staff & 165 & $=55^{\frac{165}{802} \times 267}$ \\
\hline \multicolumn{2}{|c|}{ Amount } & 802 & 267 \\
\hline
\end{tabular}

Data were collected using a questionnaire and measured using a Likert scale. Data were analyzed using Structural Equation Modeling (SEM) with the help of the Amos 22 program. Mathematically, the research model can be stated as follows:

$\eta 1=\gamma 1.1 \xi 1+\zeta 1$

$\eta 2=\gamma 1.1 \xi 1+\zeta 1$

$\eta=\gamma 2.1 \xi 1+\gamma 2.2 \xi 2+\zeta 2$

Or

Worker productivity $\quad=\gamma 11$ competency standard $+\gamma 11+\zeta 1$

Productivity of Production Unit $=\gamma 21$ competency standard $+\zeta 2$

Operasinal excellence $\quad=\gamma 21$ competency standard $+\gamma 12$ worker productivity $+\gamma 13$ work unit productivity $+\zeta 3$

Hypothesis testing was done in 2 (two) ways, namely testing the direct effect and testing the indirect effect with organizational commitment as the mediator variable. The concept of indirect effects testing used a model developed by(Baron \& Kenny, 1986), by using the Sobel calculator.

\section{RESULTS AND DISCUSSION}

Descriptive Hypothesis Testing

The model used for testing the first hypothesis was the one-sample test. The test results are 


\section{International Journal of Business Management and Economic Review}

Vol. 4, No. 03; 2021

ISSN: 2581-4664

as described below:

\section{Table 2. One-Sample Test Results}

\begin{tabular}{|l|l|l|l|l|l|l|}
\hline & \multicolumn{2}{|l|}{ Test Value $=3.41$} & \multicolumn{2}{l|}{} \\
\cline { 2 - 7 } & $\mathrm{t}$ & $\mathrm{df}$ & $\begin{array}{l}\text { Sig (2- } \\
\text { tailed) }\end{array}$ & $\begin{array}{l}\text { Mean } \\
\text { Difference }\end{array}$ & \multicolumn{2}{l}{$\begin{array}{l}\text { 95\% Confidence Interval } \\
\text { of the Difference }\end{array}$} \\
\cline { 5 - 7 } & & & Lower & Upper \\
\hline $\begin{array}{l}\text { Competency } \\
\text { standards }\end{array}$ & 139.508 & 266 & .000 & 25.303 & 24.95 & 25.66 \\
\hline Worker Productivity & 137.092 & 266 & .000 & 24.801 & 24.45 & 25.16 \\
\hline $\begin{array}{l}\text { Productivity of the } \\
\text { Production Unit }\end{array}$ & 178.888 & 266 & .000 & 42.416 & 41.95 & 42.88 \\
\hline $\begin{array}{l}\text { Operational } \\
\text { Excellence }\end{array}$ & 115.753 & 266 & .000 & 21.052 & 20.69 & 21.41 \\
\hline
\end{tabular}

Source: Primary Data, 2020 (processed).

Based on Table 2 shows that the results of testing this descriptive hypothesis are accepting $\mathrm{Ha}$ and rejecting $\mathrm{Ho}$, because the sign is 0.005 , thus it explains that all of the research variables have a significance value below $\alpha=0.05(5 \%)$, so that all variables in this research said to have gone well.

\section{Direct Hypothesis}

The structural model analysis that explains the effect test between variables is presented in the following path diagram:

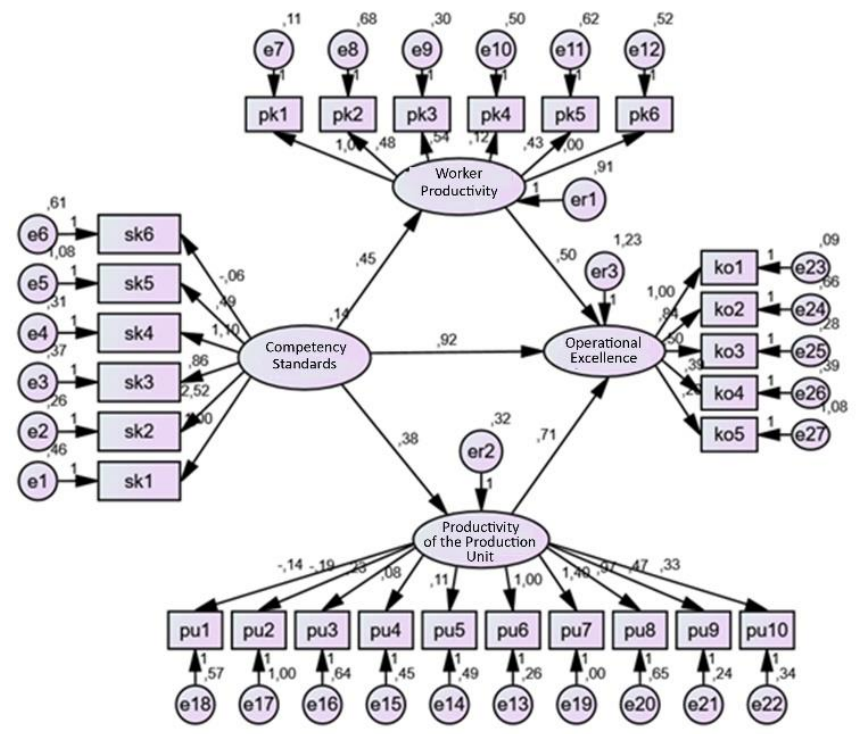

Figure 2. Test Result

The test results of the full model for testing the direct effect hypothesis after fulfilling the SEM assumptions are more clearly shown in the following table: 
Table 3. Direct Hypothesis Test Results

\begin{tabular}{|l|l|l|l|l|l|}
\hline \multicolumn{2}{|l|}{ S.E. } & \multicolumn{2}{l|}{ Estimate } \\
\hline$\left(\mathrm{H}_{2}\right)$ & $\begin{array}{l}\text { There is an effect of standardization of the } \\
\text { competence of mechanical workers on worker } \\
\text { productivity }\end{array}$ & 0.263 & 0.053 & 8.626 & $* * *$ \\
\hline$\left(\mathrm{H}_{3}\right)$ & $\begin{array}{l}\text { There is an effect of standardization of the } \\
\text { competence of mechanical workers on the } \\
\text { productivity of the production unit }\end{array}$ & 0.365 & 0.060 & 6.323 & $* * *$ \\
\hline$\left(\mathrm{H}_{4}\right)$ & $\begin{array}{l}\text { There is an effect of worker productivity on the } \\
\text { company's operational excellence }\end{array}$ & 0.368 & 0.057 & 8.919 & $* * *$ \\
\hline$\left(\mathrm{H}_{5}\right)$ & $\begin{array}{l}\text { There is an effect of the productivity of the } \\
\text { production unit on the company's operational } \\
\text { excellence }\end{array}$ & 0.330 & 0.052 & 13.772 & $* * *$ \\
\hline$\left(\mathrm{H}_{6}\right)$ & $\begin{array}{l}\text { There is an effect of competency standardization } \\
\text { on the company's operational excellence }\end{array}$ & 0.531 & 0.092 & 10.101 & $* * *$ \\
\hline
\end{tabular}

Source: Primary data, 2020 (processed)

From the test findings in Table 2, it can be explained as follows:

1. H2: Hypothesis 2 test results in a CR value of 8.626 with a significance value of 0.000 . These values are in accordance with the requirements for acceptance of the hypothesis (H2), namely the CR value of 8.626> 1.97 with a significance level of $<0.05$. Thus Ha4 accepted that competency standard has an effect on the work productivity of the employees of PT. Mifa. This indicates that the higher the competency standards possessed by employees will have a positive and significant impact on the increase in employee productivity by 0.263 because the competency standards will increase employee productivity. The results of this research are also consistent with the theory put forward by (Winarno, 2016), that proved that competency standards for appropriate employees will provide an increase in employee work productivity.

2. H3: Hypothesis 3 test results in a CR value of 6.323 with a significance value of 0.000 . These values are in accordance with the requirements for acceptance of the hypothesis (H3), namely the CR value of 6.323> 1.97 and with a significance level of $<0.05$. Thus Ha5 accepted that the competency standard possessed by employees has an effect on the productivity of the production unit of PT. Mifa. This indicates that the competency standard can have an effect in increasing the productivity of the production unit for the better of 0.365. The results of this research are consistent with(Yousefi, Taherkhani, \& Ghardashkhani, 2014), which stated that competence has an influence on improving employee performance.

3. H4: Hypothesis 4 test shows that it produces a CR value of 8.919 with a significance value of 0.000. These values are in accordance with the requirements for acceptance of the hypothesis (H4), namely the CR value of 8.919> 1.97 and the probability <0.05. Thus Ha6 accepted that worker productivity has an effect on operational excellence at PT. Mifa. This 
Vol. 4, No. 03; 2021

ISSN: 2581-4664

indicates that adequate worker productivity will have a positive impact on increasing the company's operational excellence by 0.368 . The results of this research are consistent with the research conducted by(Abdullahi, Gwadabe, Bature, \& Ibrahim, 2018)stated that the productivity of the production unit in a company can increase operational excellence for the better.

4. H5: Hypothesis 5 test results in a CR value of 13.772 with a significance value of 0.000 . These values are in accordance with the requirements for acceptance of the hypothesis (H5), namely the CR value of $13.772>1.97$ with a significance level of $<0.000$. Thus Ha1 is accepted or the productivity of the company's production unit can have a significant effect on increasing the operational excellence of PT. Mifa. The productivity of the production unit owned by the company will also have a positive and real impact in order to increase the company's operational excellence by 0.330 , this is because the productivity of the production unit will be able to create a better company's operational excellence. The results of this research are consistent with the research conducted by(Booz, Allen, \& Hamilton, 2013)proved that the productivity of the production unit owned by the company is able to have an influence on increasing operational excellence, this can be explained that high productivity of the production unit will be able to create the company's operational excellence.

5. H6: Hypothesis 6 test results in a CR value of 10.101 with a significance value of 0.000 . These values are in accordance with the requirements for acceptance of the hypothesis (H6), namely the CR value is 8,919> 1.97 and the probability is <0.05. Thus Ha6 accepted that competency standards have a significant effect on the operational excellence of PT. Mifa. The results of this research are consistent with the research conducted by (Srivastava, Bartol, \& Locke, 2006)which stated that the competency standard of mechanical employees has an effect on the company's operational excellence by 0.531 . This indicates that the existence of an appropriate competency standard can have an effect on increasing operational excellence. The research results imply that the competency standards possessed by mechanics are able to have an impact on increasing the operational excellence of PT. Mifa is getting better.

\section{Indirect Hypothesis (Mediation)}

The results of testing the indirect hypothesis (mediation) are described below:

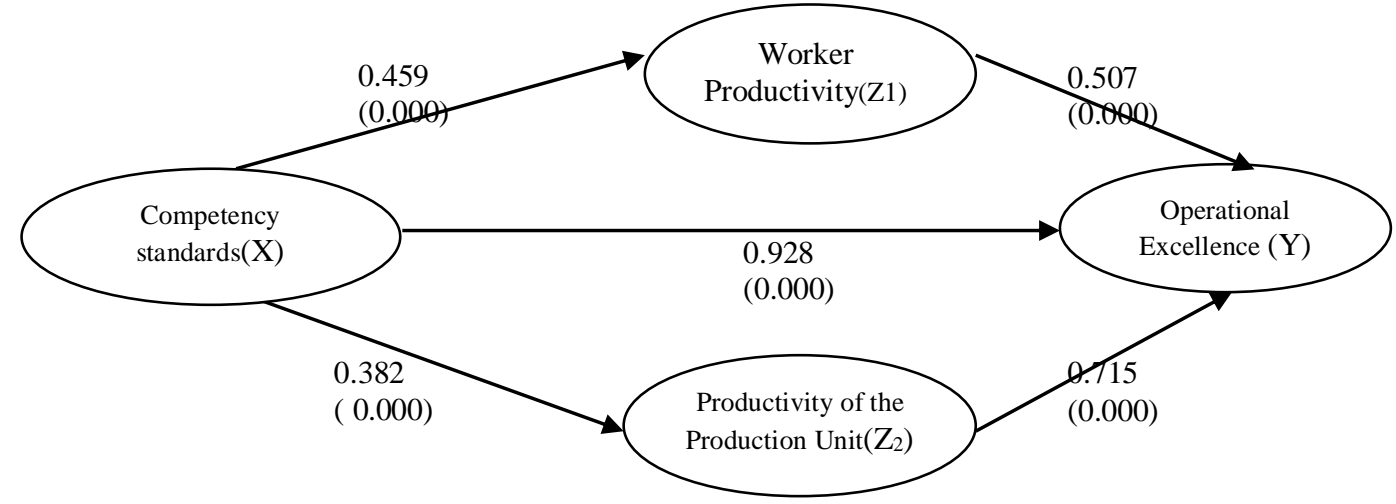

Figure 3. Influence Between Variables in the Flow Chart 


\section{International Journal of Business Management and Economic Review}

Vol. 4, No. 03; 2021

ISSN: 2581-4664

Based on Figure 3 above, the results of the indirect effect test are shown in the following table:

Table 4 Direct Effects and Indirect Effects

\begin{tabular}{|l|l|l|ll|l|l|}
\hline No & Description & Direct & Indirect & $\begin{array}{l}\text { Total } \\
\text { Effect }\end{array}$ & Information \\
\hline 1. & $\begin{array}{l}\text { Effect of competency standards } \\
\text { on worker productivity }\end{array}$ & 0.459 & $\begin{array}{l}0.459 \\
0.928 \\
=0.426\end{array}$ & $\mathrm{x}$ & 0.745 & Direct<Indirect \\
\hline 2. & $\begin{array}{l}\text { Effect of competency standards } \\
\text { on the productivity of the } \\
\text { production unit }\end{array}$ & 0.382 & $\begin{array}{l}0.382 \\
0.928 \\
=0.354\end{array}$ & $\mathrm{x}$ & 0.620 & Direct < Indirect \\
\hline 3. & $\begin{array}{l}\text { Effect of worker productivity } \\
\text { on operational excellence }\end{array}$ & 0.507 & $\begin{array}{l}0.507 \\
0.928 \\
=0.470\end{array}$ & $\mathrm{x}$ & 0.823 & Direct < Indirect \\
\hline 4. & $\begin{array}{l}\text { Effect of production unit } \\
\text { productivity on operational } \\
\text { excellence }\end{array}$ & 0.715 & $\begin{array}{l}0.715 \\
0.928 \\
=0.664\end{array}$ & $\mathrm{x}$ & 1.160 & Direct < Indirect \\
\hline 5. & $\begin{array}{l}\text { Effect of competency standards } \\
\text { on operational excellence }\end{array}$ & 0.928 & & & \\
\hline
\end{tabular}

Source: Primary Data, 2020 (processed).

From the test findings in Table 4 above, the indirect hypothesis testing results can be explained as follows

1. H7: The Influence of Competency Standards on Operational Excellence through Worker Productivity of PT. Mifa shows that the estimated parameter for testing the indirect effect of competency standards on operational excellence through worker productivity is obtained by the total effect coefficient value of 0.459 . Thus it concludes that competency standard indirectly has an influence on operational excellence through worker productivity at PT. Mifa. The results of this research have the implication that the higher the level of competency standards for mechanical employees will have an impact on increasing operational excellence through the productivity of the work units of PT. Mifa. Testing the mediating effect of standard competency variables on operational excellence through worker productivity can be explained as follows: 
Vol. 4, No. 03; 2021

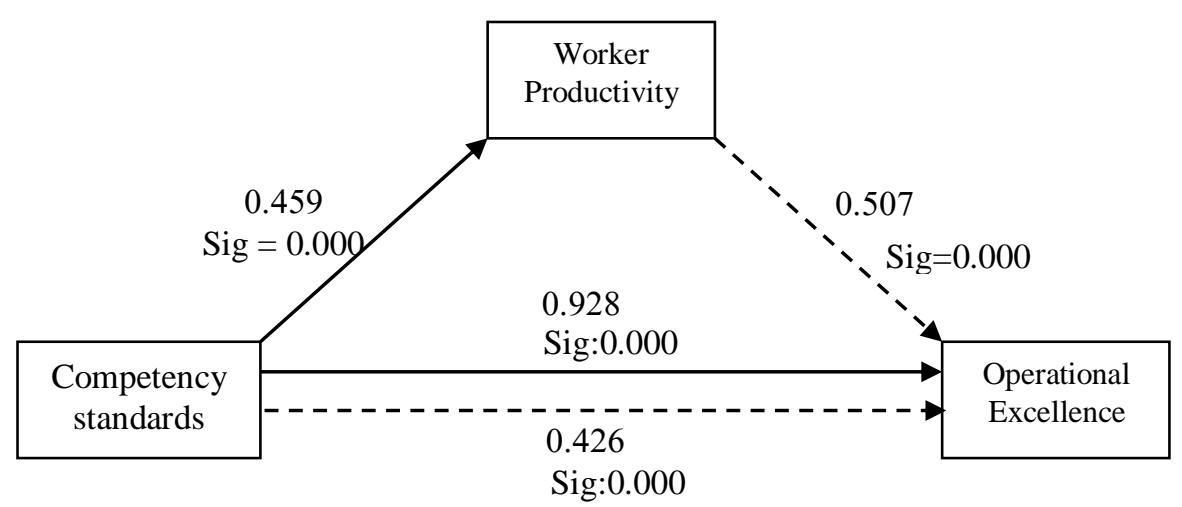

Figure 4.Testing the Mediation Effects of Hypotheses 7

Figure 4 shows that the effect of competency standards on operational excellence is positive $(0.42, \rho=0.000)$, and the influence of worker productivity on operational excellence has a significant effect $(0.507, \rho=0.000)$, and the effect of competency standards on operational excellence is significant, $(0.928, \rho=0.000)$ thus this test shows the existence of partially mediated. This is because the direct influence is greater than the indirect effect. With a direct effect that is greater than the indirect effect, it implies that the competency standards possessed by mechanics will be able to have a positive effect in increasing worker productivity and increasing operational excellence for the better.

2. H8: The Influence of Competency Standards on Operational Excellence through the Productivity of the Production Unit of PT. Mifa shows the estimation parameter for testing the indirect effect of competency standards on operational excellence through the productivity of the production unit, the total effect coefficient value is 0.382 . Thus it reveals that the competency standard of mechanical employees indirectly has an influence on operational excellence through the productivity of the production unit of PT. Mifa. Testing the mediating effect of standard competency variables on operational excellence through the productivity of the production unit can be explained as follows:

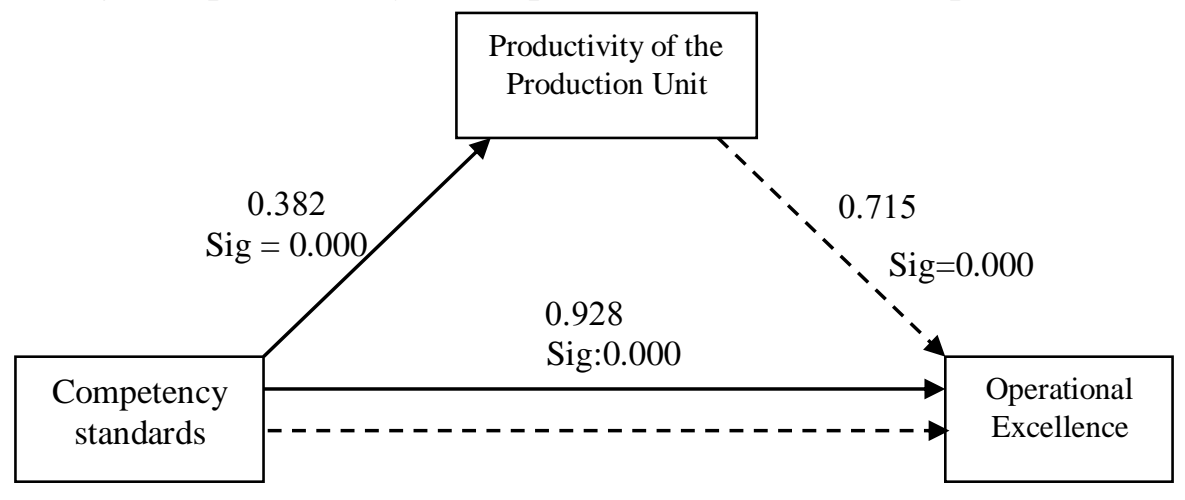

Figure 5. Testing the Mediating Effects of Hypotheses 7 


\section{International Journal of Business Management and Economic Review}

Vol. 4, No. 03; 2021

ISSN: 2581-4664

Figure 5 shows that the effect of competency standards on operational excellence is positive $(0.382, \rho=0.000)$, and the influence of productivity of production units on operational excellence has a significant effect $(0.715, \rho=0.000)$, and the effect of competency standards on operational excellence is significant. $0.928, \rho=0.000$ ) thus this test shows the existence of partially mediated. This is because the direct influence is greater than the indirect effect. With the direct effect that is greater than the indirect effect, it implies that the competency standards possessed by mechanics will be able to have a positive effect in increasing the productivity of the production unit and increasing operational excellence for the better.

\section{CONCLUSION}

The research results prove that in PT. Mifa, competency standardization of mechanical workers, company operational excellence, worker productivity and production unit productivity are good; there is an effect of competency standardization of mechanical workers on worker productivity; there is an effect of competency standardization of mechanical workers on the production unit productivity; there is an effect of worker productivity on operational excellence; there is an effect of the production unit productivity on operational excellence; there is an effect of competency standardization of mechanical workers on operational excellence; there is an effect of competency standardization of mechanical workers on operational excellence through worker productivity, and ; there is an effect of competency standardization of mechanical workers on operational excellence through production unit productivity. This research model also reveals that worker productivity and production unit productivity can be a partial mediation so that PT. Mifa achieves operational excellence. It can be said that by increasing the competency standards of mechanical workers, it will have an impact on the achievement of operational excellence either directly or through the mediation of worker productivity and productivity of production units. All these findings reveal that this research model can be implemented in the research object, namely PT. Mifa to achieve operational excellence for its company. For future research, researchers are currently encouraging that this tested model can be further developed by adding other variables such as workload and work stress related to the achievement of company operational excellence.

\section{REFERENCES}

Abdullahi, M. S., Gwadabe, Z. L., Bature, M., \& Ibrahim. (2018). Effect Of Training And Development On Employee's Productivity Among Academic Staff Of Kano State Polytechnic, Nigeria. Asian People Journal (APJ), 1(2), 264-286.

Baron, R. M., \& Kenny, D. A. (1986). The moderator-mediator variable distinction in social psychological research: Conceptual, strategic, and statistical considerations. Journal of Personality and Social Psychology, 51(6), 1173.

Booz, Allen, \& Hamilton. (2013). Achieving Operational Excellence in China, Strategic Need and Practical Solution. Retrieved December 20, 2019, from Booz Allen website: boozallen.com/about/article_newsideas $/ 2418283$ ? Tid=934306\& lpid=66005

Edgeman, R., \& Eskildsen, J. (2014). Modeling and Assessing Sustainable Enterprise Excellence. Business Strategy and the Environment, 23(3), 173-187. https://doi.org/10.1002/bse.1779 


\section{International Journal of Business Management and Economic Review}

Vol. 4, No. 03; 2021

ISSN: 2581-4664

Engko, C. (2008). engaruh Kepuasan Kerja Terhadap Kinerja Individual Dengan Self Esteem dan Self Efficacy Sebagai Variabel Intervening. Jurnal Bisnis Dan Akuntans, 10(1).

Hartati, I. (2005). Pengaruh Kesesuaian Kompetensi dan Motivasi Kerja terhadap Kinerja Pegawai pada Sekretariat Daerah Kabupatcn Malang. Jurnal Eksekutif, 2(1), 63-80.

Margiati, L. (2010). Pengaruh Kecerdasan Emosi, Karakteristik Individu, Self Leadership, Komitmen Pada Profesi, Iklim Organisasi terhadap Kinerja dan Karier Dosen pada Perguruan Tinggi Swasta Koperti Wilayah VII Jawa Timur. Universitas 17 Agustus 1945, Surabaya.

Nyiramahoro, B., \& Shooshina, N. (2001). Creating and Measuring Shareholder Value, Applicability and Relevance in Selected Swedish Companies. Gotheborg University.

Rahmah, N. (2019). Produktivitas Tenaga Kerja: Pengertian, Faktor-faktor yang Mempengaruhinya, dan Manfaat Pengukuran Produktivitas. Retrieved January 1, 2021, from https://www.pengadaanbarang.co.id/ website: https://www.pengadaanbarang.co.id/2019/09/produktivitas-tenagakerja.html\#: :text=Produktivitas tenaga kerja adalah tingkat,satuan volume\%2Fhari-orang.

Ratminto, \& Winarsih, A. S. (2008). Manajemen Pelayanan: Pengembangan Model Konseptual, Penerapan Citizen's Charter dan Standar Pelayanan Minimal. Yogyakarta: Pustaka Pelajar.

Sobandi, B., Sedarmayanti, Utomo, T. W. W., Dawud, J., Nugraha, \& Kusumah, I. B. (2006). Desentralisasi dan tuntutan penataan kelembagaan daerah. Bandung: Humaniora.

Srivastava, A., Bartol, K. M., \& Locke, E. A. (2006). Empowering Leadership in Management Teams: Effects on Knowledge Sharing, Efficacy, And Performance. The Academy of Management Journal, 49(6), 1239-1251. https://doi.org/10.5465/AMJ.2006.23478718

Surjadi. (2009). Pengembangan Kinerja Pelayanan Publik. Bandung: Refika Aditama.

Wibowo. (2016). Manajemen Kinerja (kelima). Jakarta: PT. Rajagrafindo Persada.

Winarno, S. H. (2016). Analisis Peningkatkan Produktivitas Kerja Melalui Program Pelatihan (Studi Kasus: BLK Kelurahan Malakasari Jakarta Timur). Widya Cipta, VIII(2), 148-155.

Yasir, M., \& Majid, A. (2017). Impact of knowledge management enablers on knowledge sharing: Is trust a missing link in SMEs of emerging economies? World Journal of Entrepreneurship, Management and Sustainable Development, 13(1), 16-33. https://doi.org/https://doi.org/10.1108/WJEMSD-02-2016-0010

Yousefi, R., Taherkhani, S., \& Ghardashkhani, N. (2014). The Effect of Knowledge Management on Organizational Learning and Performance of Education Department of Abhar County. Kuwait Chapter of Arabian Journal of Business and Management Review, 3(12), 55-59. https://doi.org/10.12816/0018847 